\title{
A New Cynodont from the Late Triassic Los Colorados Formation (Argentina, South America) Reveals a Novel Paleobiogeographic Context for Mammalian Ancestors
}

\section{C. GAETANO ( $\sim$ lcgaetano@gl.fcen.uba.ar)} Instituto de Estudios Andinos "Don Pablo Groeber" (IDEAN, UBA-CONICET)

\section{F. ABDALA}

University of the Witwatersrand. Johannesburg

\section{F. D. SEOANE} Instituto de Estudios Andinos "Don Pablo Groeber" (IDEAN, UBA-CONICET)

\section{A. TARTAGLIONE}

Forschungs-Neutronenquelle Heinz Maier-Leibnitz (FRM II), Technische Universität

\section{SCHULZ}

Forschungs-Neutronenquelle Heinz Maier-Leibnitz (FRM II), Technische Universität

\section{A. OTERO}

Universidad Nacional de La Plata. La Plata

\section{J. M. LEARDI}

University of Buenos Aires

\section{APALDETTI}

Universidad Nacional de San Juan

\section{KRAPOVICKAS}

Instituto de Estudios Andinos "Don Pablo Groeber" (IDEAN, UBA-CONICET)

\section{E. STEINBACH}

Instituto de Estudios Andinos "Don Pablo Groeber" (IDEAN, UBA-CONICET)

\section{Research Article}

Keywords: micro-tomography, Probainognathia

Posted Date: December 29th, 2021

DOI: https://doi.org/10.21203/rs.3.rs-1182235/v1

License: (c) (i) This work is licensed under a Creative Commons Attribution 4.0 International License. Read Full License 
Page $2 / 20$ 


\section{Abstract}

Probainognathia is a derived lineage of cynodonts which encompass Mammalia as their crown-group. The profuse record of probainognathians from the Carnian of Argentina contrasts with their Norian representation, with only one named species. Here we describe a new probainognathian, Tessellatia bonapartei gen. et sp. nov., from the Norian Los Colorados Formation of the Ischigualasto-Villa Unión Basin of Argentina. The new taxon, represented by a partial cranium with articulated lower jaws, was analyzed through neutron and X-rays micro-tomography $(\mu \mathrm{CT})$. The high-resolution neutron $\mu \mathrm{CT}$ data allowed the identification of a unique character state combination, including features inaccessible through traditional techniques. We constructed the largest phylogenetic data-matrix of non-mammalian cynodonts. The new species and its sister-taxon, the Brazilian Therioherpeton, are recovered as probainognathians, closely related to Mammaliamorpha. We conducted the first quantitative paleobiogeographic analysis of non-mammalian cynodonts, focusing in probainognathians. The results indicate that Probainognathia and Mammaliamorpha originated in Brazil, which was an important center of diversification during the Triassic. Finally, China is identified as the ancestral area of Mammaliaformes. These new findings, besides adding to the knowledge of the poorly represented Norian cynodonts from the Los Colorados Formation, are significant to improve our understanding of probainognathian diversity, evolution, and paleobiogeographic history.

\section{Introduction}

Probainognathia (Synapsida: Cynodontia) is one of the two main clades of derived cynodonts (Eucynodontia), presently represented by Mammalia [1, 2]. With the exception of the highly-specialized, herbivorous tritylodontids, non-mammaliaform probainognathians are mostly small- to medium-sized animalivorous forms. The oldest probainognathian remains are known from Middle Triassic deposits from Gondwana. After an initial diversification during the early Late Triassic (Carnian), basal (nonmammaliaform) probainognathians are also found in Norian, Rhaetian, and Jurassic-to-Cretaceous deposits [3]. The abundant Carnian record of the lineage in Argentina is in strong contrast with their poor Norian representation. Among the six Norian probainognathian species previously recognized from Gondwana, four were reported from Brazil, one from Argentina, and one from southern Africa (but see Supplementary Information); most of them only represented by a single or a few fragmentary specimens. This is in concordance with the general scarcity of cynodonts from Norian strata globally $[3,4]$ (see Supplementary Information).

The Norian Los Colorados Formation of the Ischigualasto-Villa Unión Basin of Argentina is worldwide renowned for its vertebrate fossil record $[5,6]$. One of the youngest dicynodonts of Gondwana, Jachaleria colorata, is represented in the lower levels of the unit [7-9]. The upper levels of the Los Colorados Formation represent a different faunal assemblage [10] that have provided one of the oldest turtles [11, 12]; basal and derived representatives of the crocodylian lineage $[5,13-16]$; and a number of relatively well-represented dinosaurs [5, 17-22], key to the understanding of the rise of this group as it is the earliest assemblage where dinosaurs are dominant components of the ecosystem [23]. Non- 
mammaliaform cynodonts (NMC) are scarcely represented in this unit [14,24,25]. Only two partial skulls of Chaliminia musteloides [24, 25] and a few fragmentary postcranial elements of an unnamed taxon [5, $14,26]$ have been reported. They are among the oldest tritheledontids, a lineage of mainly Gondwanan cynodonts that have been proposed to be closely related to basal mammals [25, 27-29]. Renovated exploration efforts since 2014 in the Los Colorados Formation led to new findings at the Parque Nacional Talampaya (La Rioja province, north-western Argentina), including five cynodont specimens whose preliminary study suggests that at least three of them might represent previously unrecognized taxa [30]. Recent geochronological studies of the unit suggest that the richest and most renowned faunal assemblage ('La Esquina local fauna'), found in the upper levels of Los Colorados Formation, might be mid-Norian ( 220-211Ma) in age [31, 32].

Herein we describe a new species of derived NMC found in the upper levels of the Los Colorados Formation (Fig. 1) represented by a partial cranium with articulated lower jaws. The specimen was analyzed through neutron and X-rays micro-tomography $(\mu \mathrm{CT})$. Although, only scarcely used to analyze fossil specimens, it has become clear that neutron $\mu \mathrm{CT}$ complements very well-with X-ray $\mu \mathrm{CT}$ and it allows circumventing some problems that might arise from the latter methodology depending on the characteristics of the fossil sample studied [33, 34]. In addition, we constructed the most comprehensive data-matrix for non-mammalian cynodonts published to date, allowing us to analyze the phylogenetic relationships of the new species and the main hypotheses regarding the ancestry of mammaliaforms and their close relatives. We also present the first quantitative paleobiogeographic analysis of nonmammalian cynodonts, focusing in probainognathians. Our results provide new insights on the understanding of the evolutionary and paleobiogeography history of Probainognathia. In particular, the new finding improves our knowledge on the diversity of the poorly represented Norian forms in the rich fauna of the Los Colorados Formation, north-western Argentina.

\section{Results}

\section{SYSTEMATIC PALEONTOLOGY}

\section{THERAPSIDA [35]}

\section{CYNODONTIA [36]}

\section{EUCYNODONTIA [37]}

\section{PROBAINOGNATHIA [38]}

Tessellatia gen. nov.

Type species. Tessellatia bonapartei. 
Etymology. From the Latin tessella (each one of the tiles composing a mosaic), in reference to the combination of basal and derived features recognized in this taxon.

Diagnosis. Same as for species.

Tessellatia bonapartei sp. nov. (Figure 2)

Etymology. In honor to the late Dr. José F. Bonaparte, who worked unrelentingly to broaden our knowledge of Mesozoic ecosystems and described the first cynodont remains from the Los Colorados Formation.

Holotype. PULR-V121, partial cranium, represented by the snout and orbital region, with articulated lower jaws.

Locality and horizon. Uppermost third of the Los Colorados Formation, Talampaya National Park, La Rioja Province, Argentina. The specimen was found in a massive- to parallel-laminated sandy mudstone interval locally interbedded with parallel- to rippled- laminated sandstone, representing deposition in a floodplain setting sporadically affected by sandy splays from the fluvial channels. See Supplementary Information online for further details on the geological framework.

Diagnosis. (autapomorphies are marked with an asterisk). Small probainognathian with the anteorbital region notably longer than the height of the skull at the level of the anterior margin of the orbit. Alveolar margin of the maxilla sigmoidal, with its dorsal-most point at the level of the canine. Ventrally bowed secondary osseous palate with deep, narrow, lateral groove for the lower postcanines. Contribution of the palatine to the secondary palate relatively long, subequal to that of the maxilla. Masseteric fossa and low coronoid process posterior to the lower tooth row*. Angular process ventrally projected, well-developed, and semicircular in outline*. Horizontal ramus of the dentary comparatively low and lacking a welldeveloped platform lateral to the posterior postcanines. Broad groove between the lateral wall of the dentary and the postcanine alveoli*. Alveolar margin of the dentary anteriorly elevated. Posterior-most lower incisor smaller than the canines and postcanines. Large upper canine and small lower canine. Upper postcanine count larger (14) than the lower postcanines (7), with the last six upper postcanines lacking a lower counter-element*. Postcanines single rooted. Upper postcanine tooth row extends posteriorly to the anterior margin of the orbit. Upper postcanines separated from each other, with teeth interspacing progressively shorter posteriorly. Posterior upper postcanines with convex labial and concave lingual surfaces, and bearing a centrally placed, symmetrical main cusp with convex mesial and distal margins flanked by smaller, lingually placed accessory cusps. Lower postcanines, comparatively larger than uppers, with a large, asymmetrical, mesial main cusp followed by smaller distal accessory cusps and bearing a lingual cingulum on the distal portion of the teeth.

\section{Anatomical remarks}

Selected traits are discussed below in a comparative framework. Relevant references of the taxa considered are provided in Supplementary Table S2. A complete anatomical description of Tessellatia and further comparisons are provided in the Supplementary Information. 


\section{Skull}

The bones of the skull are fragmentary, including portions of the right premaxilla, maxillae, right nasal, frontals, lacrimals, palatines, and pterygoids (Fig. 2). Two elements are too incomplete to be confidently determined, but they might represent parts of the basisphenoid and prootic (Supplementary Figs. S3-4). The skull is relatively high and inflated immediately anterior to the orbits, at the level of the lacrimals. The snout of Tessellatia is constricted posterior to the canines, resulting in a pin-shaped rostrum (Fig. 2e-f), a condition similar to that of Riograndia, Irajatherium, Pachygenelus monus, Prozostrodon, Pseudotherium, and Brasilitherium (but not Therioherpeton, Elliotherium, and Chaliminia) among derived non-tritylodontid probainognathians (NTP).

The alveolar margin of the maxilla has a sigmoidal outline (Fig. 2b-c). The maxillary canal in Tessellatia is completely ossified (Fig. 3) and separated from the maxillary sinus as in derived probainognathians including mammaliaforms (see Benoit et al., 2016, 2020). The short infraorbital canal and posteriorly placed infraorbital foramen of Tessellatia (Fig. 2c; infraorbital foramen 2 in [39]; see [40]), shared with derived probainognathians, suggest the presence of a mobile rhinarium with sensitive vibrissae (see [40, 41]).

A remarkably large facial exposure of the lacrimal (Fig. 2b-c) is a distinctive feature of Tessellatia that, among probainognathians, is only recognized in some tritylodontids. Unlike in other probainognathians, Tessellatia shares with its sister-group Therioherpeton, some tritylodontids, and Morganucodon, a short lacrimal-frontal contact and frontals with short anterolateral projections.

Tessellatia is comparable to early-diverging probainognathians rather to relatively derived forms in the presence of an orbital process of the palatine excluded from the orbital wall and not contacting the frontal. Unlike in derived NTP, in which the secondary palate extends to the end of the tooth row or posterior to it, the osseous secondary palate of Tessellatia ends anteriorly to the antepenultimate upper postcanine (PC13; Fig. 2e-f). On the other hand, Tessellatia shares with some derived probainognathians (i.e., Chaliminia, Elliotherium, Irajatherium, and Pachygenelus), traditionally grouped in Tritheledontidae (see [25]), the presence of a ventrally bowed osseous secondary palate reaching the level of the crown of the upper postcanines (Fig. 2b-c). In these forms, deep, narrow grooves are present medial to the upper tooth rows, posterior to the maxillae-palatines suture (Fig. 2e-f).

\section{Lower jaw}

The dentary is relatively robust, high, and lateromedially wide (Fig. 2b-c, h). Unique of Tessellatia is the presence of a broad groove between the lateral wall of the dentary and the postcanine alveoli (Fig. $2 \mathrm{~g}$ ). This groove starts at the posterior half of pc2 and ends laterally to the penultimate lower postcanine (pc6). The anterior region of the dentary is dorsally projected regarding the postcanine line in Tessellatia (Fig. $2 \mathrm{~b}-\mathrm{c}, \mathrm{h}$ ) as well as in many derived NTP and the mammaliaform Morganucodon. The shape and development of the angular process of the dentary of Tessellatia distinguishes it from other taxa.

\section{Dentition}


The upper dentition is constituted by at least one incisor, one canine, and 14 postcanines (1+?I/1C/14PC) (Fig. 2b-f). The lower dental formula is formed by at least one incisor preserved in position on the dentary and an isolated fragment of another, one canine, and seven postcanines (2+?i/1c/7pc) (Fig. 2b-c, g-h). Incisors are small non-procumbent teeth (Fig. 2b-h), unlike those of some tritheledontids (see [25]) such as Chaliminia, Pachygenelus, and Riograndia. The presence of a large upper canine (1.5 or more the mesiodistal length of the first postcanine) in conjunction with a reduced lower one (the same mesiodistal length or less of the first postcanine) (Fig. 2b-h) is only recorded in Tessellatia and Riograndia among NMC and shared with the early mammaliaform Morganucodon. On the other hand, in Prozostrodon, Pachygenelus, and Brasilodon as well as in more basal probainognathians (Trucidocynodon, Probainognathus, Lumkuia, Aleodon, and Chiniquodon), both the upper and lower canines are enlarged. Both lower and upper canines are reduced in Chaliminia. The general structure of the postcanines of Tessellatia (Fig. 2i-j) is similar to those of tritheledontids (see [25]). A reduced number of lower postcanines (7) regarding the number of upper ones (14) is a distinctive feature of Tessellatia among NMC (Fig. 2b-h). It is noteworthy that the lower tooth row is very short when compared to the upper one. The last lower postcanine (pc7) would have occluded approximately between PC8 and PC9. In this scenario, the last five upper postcanines lacked a lower counterpart.

\section{Comparisons with Chaliminia musteloides}

Chaliminia is the only named cynodont represented by cranial remains previously described from the Los Colorados Formation. It is represented by specimens of comparable size than Tessellatia. Hence, we deem it important to highlight some additional differences of the published specimens of Chaliminia (the holotype PVL 3857 and the referred specimen PULR 088) with the holotype of Tessellatia. Tessellatia has a proportionally longer snout when compared to the height of the skull at the level of the anterior margin of the orbit (Supplementary Table S3). When compared to the holotype of Chaliminia, Tessellatia has a comparatively slenderer dentary. On the other hand, the proportions of the horizontal ramus of the dentary are similar between Tessellatia and the referred specimen of Chaliminia (PULR 081) (Supplementary Table S4). However, it is important to take into account that the anterior end of the skull and lower jaws are missing in Tessellatia; a longer skull and dentary would mean a longer snout and a slenderer horizontal ramus of the dentary, accentuating the differences in these proportions with the specimens of Chaliminia.

In addition, Tessellatia (Fig. 2) differs from Chaliminia in the presence of a constriction in the snout posterior to the canines that results in a pin-shaped rostrum; a strongly concave posterior margin of the secondary palate; a notably short lower tooth row with the ascending coronoid process of the dentary well-posterior to the last lower postcanine, slightly sloping dorsally at the level of the orbits; the masseteric fossa does not reach the level of the last lower postcanine; a broad groove between the lateral wall of the dentary and the postcanine alveoli; and small non-procumbent lower incisors (Fig. 2). Tessellatia lacks the strong osseous platform lateral to the last lower postcanines observed in the holotype of Chaliminia. The lower canine of Tessellatia has approximately the same diameter than the first lower postcanine, as measured at the upper portion of the root, whereas the lower canine of 
Chaliminia is markedly larger than the postcanines. Unlike the condition of Chaliminia, there is no lower post-canine diastema in Tessellatia.

Despite sharing the general morphology, there are some differences in the postcanine dentition between Tessellatia and Chaliminia. Unlike the convex labial and concave lingual surface of the upper postcanines of Tessellatia, in Chaliminia there is a central blunt crest separating mesial and distal depressions labially whereas the lingual surface is almost flat. Contrary to what is observed in Tessellatia, the lower postcanines of Chaliminia are mesiodistally shorter than the upper ones. In Chaliminia, the lower postcanines show more conspicuous, higher distal accessory cusps, more closely placed to the main cusp than in Tessellatia.

\section{Phylogenetic results}

The parsimony analysis of 151 characters and 73 operational taxonomic units (OTUs) resulted in 29,304 most parsimonious trees (mpt) of 786 steps. The strict consensus is poorly resolved. There is a large polytomy including a wide array of taxa. A basal group of Cynodontia (represented by Late Permian forms), Epicynodontia, and Eucynodontia, as usually conceived [2, 28, 42], are not recovered. Only Cynognathia and a clade including some derived probainognathians are recovered by our analysis. Tritylodontidae, the only clade with a strong support, is nested among the latter group.

A second analysis excluding three wild-card taxa (i.e., Diegocanis, Charruodon, and Microconodon) retrieved $200 \mathrm{mpt}$ of 782 steps, whose strict consensus is better resolved than with the complete dataset (Fig. 4). A basal group of Late Permian cynodonts is followed by Cynosaurus, a node that perhaps represents the Epicynodontia level. The next node is a large polytomy including several terminals. Traditional taxa of Probainognathia, such as Chiniquodon, Trucidocynodon, Ecteninion, Candelariodon, Probainognathus + Bonacynodon, and Aleodon cromptoni + Aleodon brachyrhamphus, are recovered as part of the mentioned polytomy that also includes basal members of Epicynodontia. Cynognathia and Tritylodondidae form monophyletic groups as in the complete analysis. This is not the case for Tritheledontidae whose members are found to belong to the Mammaliamorpha clade (as defined by [43]), as stem-taxa to Tritylodontidae or to Mammaliaformes. According to this, Mammaliamorpha includes tritylodontids, mammaliaforms, and a number of derived probainognathians. Tessellatia is recovered as sister-group of the Brazilian Therioherpeton based on two unambiguous synapomorphies: axis of the posterior region of the maxillary tooth row directed towards the center of the subtemporal fossa (character 98:1) and transverse axis of crown strongly oblique to midline axis of the skull (character 114:1). The clade formed by Tessellatia + Therioherpeton is in a basal position among the reducedprobainognathian clade, as the sister-group to the group including Protheriodon and Mammaliamorpha. The clade Protheriodon + Mammaliamorpha is supported by two unambiguous synapomorphies: a relatively long secondary palate (character 48:1; which is shorter in Tessellatia and Therioherpeton) and snout longer than the temporal region (character 10:0; unknown in Tessellatia and shorter in Therioherpeton). The absence of the prefrontal and postorbital bones (character 4:1 and 6:2), a slender zygomatic arch (character 17:0), a moderate lateral expansion of the braincase (character 28:1), a reduced lower canine (character 96:1), and a unilateral postcanine occlusion without forming a 
consistent pattern between upper and lower teeth (character 99:1) are unambiguous synapomorphies of the clade formed by Tessellatia + Therioherpeton and Mammaliamorpha.

A traditional Probainognathia is portrayed in the majority rule consensus tree of the reduced, second analysis (Supplementary Fig. S5). It shows a basal polytomy integrated by Candelariodon, a chiniquodontid clade (Chiniquodon + Aleodon), and a clade with remaining probainognathians, which includes a polytomy formed by three clades: (Bonacynodon + Probainognathus), (Trucidocynodon + Ecteninion), and the other probainognathians. In this topology, the placement of Lumkuia, the oldest and only basal Probainognathia from South Africa, is counterintuitive, and different to previous phylogenies in which it was recovered as the basal-most Probainognathia (e.g., $[2,43])$ or as the basal-most Eucynodontia, stem to Cynognathia and Probainognathia (e.g., [42]). In our majority rule tree, basal-most Probainognathia are represented by a group of largely South American Late Triassic taxa.

\section{Probainognathian paleobiogeography}

A Bayesian Binary Markov Chain Monte Carlo (BBM) analysis of 100,000 cycles and 100 chains was performed, including nine a priori determined areas of provenance (Supplementary Table S1) and allowing the maximum number of areas per node. The study was based on the probainognathian clade as shown in the majority rule consensus tree (Supplementary Fig. S5) obtained from the analysis of the pruned dataset (70 OTUs, 151 characters). Additionally, we performed a Hausdorf's [44] manual optimization of Probainognathia, Mammaliamorpha, and Trityldontidae nodes (Supplementary Tables S5-8).

The results (Fig. 5) indicate that the paleobiogeographic history of probainognathians was dominated by dispersions (22 events) and sympatric speciation events (18 events), followed by vicariances (13 events) and with a single extinction event. Probainognathia originated in Brazil (87.29\%) and this was followed by a large and relatively quick increase in the diversity. This diversification event included the origin of Mammaliamorpha in this region (97.31\%). Hausdorf's optimization indicates the same results for Probainognathia and Mammaliamorpha nodes (Supplementary Tables S5-6).

According to our results, mammaliamorphs thrived in Brazil and experimented a few dispersions to Argentina ( 2 events), China ( 1 event), and North America (1 event). It is in China where the origin of Mammaliaformes is expected (52.03\%). However, it must be noted that we did not include Gondwanodon and Tikitherium, from the Late Carnian-Early Norian Tiki Formation (Madhya Pradesh, India), in our analysis as they are both represented by an isolated tooth which is even incompletely preserved in the case of Gondwanodon [45-47]. Although never tested phylogenetically, Gondwanodon has been considered to be closely related to Morganucodon $[48,49]$. Tikitherium, originally interpreted to be related to Morganucodon, is now regarded as a docodontan, more closely related to the Rhaetian Delsatia and Woutersia from France [50]. The Tiki Formation records the only faunal assemblage from the Triassic of Gondwana featuring remains of mammaliaforms (in fact, the oldest record of the group) and the early recognition of two mammaliaforms with clearly different tooth patterns suggests an undocumented worldwide evolution of this group. By the end of the Norian, dispersion events from Brazil to South Africa 
are identified. In this latter region, they diversified and dispersed to China (1 event) and North America (1 event). The origin of Tritylodontidae is inferred to have occurred in South Africa (28.44\%), whilst Hausdorf's optimization indicates that the origin of this group occurred in China (Supplementary Table S7).

\section{Discussion}

There is a profuse Triassic record of cynodonts in the Ischigualasto-Villa Union Basin of Argentina, particularly remarkable in the Carnian Chañares and Ischigualasto formations [51, 52]. The representation of this group becomes extraordinarily scarce in the fossil-rich Los Colorados Formation ('La Esquina local fauna'), the youngest Triassic unit of the Basin, where only one species represented by two small skulls and a second putative small taxon known by a few fragmentary postcranial remains are known to date $[14,24-26]$. The finding of Tesselatia bonapartei, thus reinforces the knowledge of a subdued fauna of small animals in the Los Colorados Formation, only represented by cynodonts so far. Tessellatia displays a mosaic of basal and derived features. Despite this, it is unambiguously recovered as a derived probainognathian. Tessellatia bears a postcanine morphology very similar to that of taxa traditionally grouped in Tritheledontidae. Although this might point to a similar diet, the distinctive features in the dentition of Tessellatia (e.g., a notably reduced number of lower postcanines regarding upper ones, large upper canine in conjunction with a small lower one, and small-sized incisors) suggest a unique feedinghabit.

The cynodonts from the Los Colorados Formation fill a temporal gap in the South American record of Probainognathia, between the early Norian forms from the Brazilian Caturrita Formation and the late Norian-Rhaetian, still undescribed, cynodonts from Quebrada del Barro Formation, San Juan, Argentina [8]. The faunal association from the Los Colorados Formation also contrasts with these latter South American assemblages because it is numerically dominated by large taxa (e.g., sauropodomorphs), with only a few known specimens of the rare small-sized cynodonts present (see Supplementary Information). On the other hand, small cynodonts are diverse and/or abundant in the Caturrita and Quebrada del Barro formations $[8,53]$.

Contrasting with the limited record of Probainognathia (and cynodonts) of the Los Colorados Formation, the Late Carnian-Norian record of the Santa Maria and Caturrita formations (Brazil) shows a burst of diversity of small derived probainognathians with at least eight species [4]. In fact, the Brazilian record of the group provides most of the information regarding Probainognathia during that time in the world. $A$ second, very important pulse of diversification of this lineage is clearly headed by mammaliamorphs mostly from the early Jurassic. In this case, tritylodontids make the great difference because extreme modifications of the skull, dentition and, together with early mammaliaforms (i.e., Morganucodon and allies), of the postcranium. Tritylodontids were also abundant and diverse, with a cosmopolitan distribution, and the only cynodont lineage of this time reaching comparatively large body sizes. 
Basal and derived probainognathians are recognized during the Carnian, including some relatively earlydiverging forms that attained the largest body-masses of the Triassic representatives of the clade (e.g., Chiniquodon, Trucidocynodon; [51, 54]). During the Norian, only small-sized probainognathians are represented. This scenario suggests that the Carnian-Norian transition represented a pivotal moment for the diversity and ecology of cynodonts in general and probainognathians in particular, probably related to the Carnian Pluvial Episode [55].

According to our phylogenetic results (Fig. 4), the two taxa from Los Colorados are not closely related. Tessellatia is an early-diverging taxon whereas the comparatively more crownward positioned Chaliminia is more closely related to tritylodontids than to mammaliaforms. The calibrated phylogeny together with the quantitative paleobiogeographic analysis of probainognathians (Fig. 5) presented here point to two major diversification events. One of them took place during the Middle Triassic and the earliest Late Triassic and included the origin of Mammaliamorpha. The second occurred in the latest Rhaetian and is represented by the origin of tritylodontids and closely allied forms. According to our results, the Norian is marked by an almost absence of diversification events. It is by mid-Norian times that the origin of Mammaliaformes would have occurred; however, mammaliaforms are not recognized until the latest Triassic and Jurassic. The results of our analysis imply long ghost-lineages for many taxa, including Tessellatia, suggesting a still unrecorded history of Probainognathia.

Dispersion events from Brazil during the Carnian-earliest Norian were restricted to Argentina whereas during the late-Norian-Rhaetian dispersions are from Brazil to South Africa. This suggests that, during these two time-lapses, barriers or favorable conditions to dispersion were alternatively in place in Argentina and South Africa preventing or encouraging dispersions from Brazil. It is also interesting to note that the three dispersion events from Brazil to Argentina represented by Tessellatia, Chaliminia, and Pseudotherium were not followed by diversifications. These results highlight the importance of improving the knowledge on Norian probainognathians.

Our study reveals a new species of a probainognathian cynodont, adding to the poorly known cynodont diversity from the rich Norian faunal assemblage of the Los Colorados Formation. The phylogenetic evaluation of Tessellatia through the most comprehensive non-mammalian cynodonts data-matrix assembled to date together with the first quantitative paleobiogeographic analysis of probainognathians highlight a previously unrecognized evolutionary and biogeographic history.

\section{Methods}

\section{Micro-tomography}

The small size and delicate bones make it impossible to remove the hard rock matrix without damaging the specimens and losing important information. In order to overcome this issue, PULR-V121 was analyzed through X-ray micro-tomography in YPF Tecnología S.A. (Y-TEC, Ensenada, Buenos Aires, Argentina) using the Bruker SkyScan 1173 instrument. The equipment was set up to $100 \mathrm{kV}$ and $80 \mu \mathrm{A}$. A total of 900 images of the specimen were captured through a $360^{\circ}$ tomography (rotation step $0.4^{\circ}$ ) with 
an exposure time of $250 \mathrm{~ms}$ with two frames averaged. The experimental design resulted in a $40.01 \mu \mathrm{m}$ pixel size. The tomographic reconstruction was then produced with the software NRecon v. 1.6.9.8. Although obtaining acceptable results, the resolution was not ideal. Regrettably, the reconstructed images proved to be difficult to interpret, as bone and matrix were in some regions indistinguishable from each other. We acknowledged that this issue was probably technique-related due to the presence of ferruginous material in the sediment. Hence, we decided to perform a preliminary neutron-tomography at the RA-6 facility (Comisión Nacional de Energía Atómica, San Carlos de Bariloche, Argentina). Considering the promissory results obtained and the hypothesis that this specimen may represent a previously unregistered taxon of the very poorly represented mammalian ancestors in the late Late Triassic of Argentina, we performed a neutron tomography with the highest possible spatial resolution at the ANTARES instrument $[56,57]$ in the Forschungs-Neutronenquelle Heinz Maier-Leibnitz Zentrum (FRM II, Garching, Germany).

The specimen did not show previous radioactivity before introducing it directly to the reactor hall at ANTARES instrument. For the neutron tomography, PULR-V121 was wrapped in aluminum foil together with two additional specimens from the same stratigraphic levels (PULR-V222 and PULR-V223) to maximize the available beam-time. The package was placed in a $5 \mathrm{~cm}$ long slot of an aluminum cylinder. A small aluminum plate was fixed to the cylinder using aluminum tape to act as a floor. This stabilized the specimens during the tomography and allowed to place them as close as possible to the detector (Supplementary Fig. S1). At ANTARES, a collimation ratio of L/D=500 was used. The Andor Neo sCMOS detector was equipped with a $100 \mathrm{~mm}$ Zeiss Milvus f2.0 lens which allowed us to obtain high resolution images, with a $19.74 \mu \mathrm{m}$ pixel size. We performed a standard (white-beam), $360^{\circ}$ tomography employing a $\mathrm{Gd}_{2} \mathrm{O}_{2} \mathrm{~S}$ based neutron scintillator of $6 \mathrm{~cm} \times 6 \mathrm{~cm}$ of $20 \mu \mathrm{m}$ thickness. The exposure time was $17 \mathrm{~s}$ and each angular position (every $\sim 0.192^{\circ}$ ) was acquired three times for improving statistics. The neutron tomography took circa 17 hours and 42 minutes. In order to normalize the images obtained, 19 open beam (open shutter, no sample in the beam) and 5 dark field (closed shutter) images were taken before and after the tomographic acquisition of the fossil remains, respectively.

The images were normalized and filtered using Image-J v. 1.52p [58] software and then reconstructed with Octopus Reconstruction v. 8.9.3.4 software at the Heinz Maier-Leibnitz Zentrum facility. Posteriorly, the reconstructed images were subjected to a new filtering process with the Inverse Scale Space Filter (ISS) module implemented in KipTool [59-61]. The ISS, an edge preserving de-noising filter based on the equation formulated by Burger et al. [62], notably increased the sharpness of the images without sacrificing morphological information. The segmentation of the specimen was performed by Dr. Gaetano who also generated the 3D model of PULR-V121. Approximately two weeks after the neutron tomography, PULR-V121 showed a very low decay ratio and was possible to remove it from the reactor hall.

\section{Phylogenetic analysis}

We put together a data matrix combining those of Liu and Olsen [42] and Ruta et al. [28] considering the subsequent modifications to both of them as well as modifying or deleting some of the characters and 
character states. We also added new characters and included the new specimen PULR-V121 as well as other relevant taxa. As a result, a comprehensive data matrix including 73 taxa and 151 characters was produced. Previous scorings were revised, and corrections implemented (Supplementary Appendix S1).

A first analysis was produced after the complete data matrix. After the recognition of three wild-card taxa (i.e., Diegocanis, Charruodon, and Microconodon), we pruned them from the matrix and performed a second analysis considering only the 70 remaining taxa. TNT 1.5 software program $[63,64]$ was used for searching of most parsimonious trees. Routine used was the command xmult=level 10, that produce 14 autoconstrained replications; each replication with random sectorial searches, drifting (36 iters) and fusing (10 round), finding best score 1 time; followed by bb (bbreak) command that perform branchswapping (tree bisection reconnection) using pre-existing trees. Characters were unordered and equally weighted. The analysis of the complete matrix resulted in 29,304 most parsimonious trees (mpt) of 786 steps; whereas the second analysis resulted in $200 \mathrm{mpt}$ of 782 steps.

Most scholars agree on the putative probainognathian nature of dromatheriids, a group of small cynodonts represented by isolated teeth or fragments of mandible, mostly discovered in the Laurasia subcontinent and India [47], yet its placement was not cladistically tested. Unfortunately, removal of Microconodon (one of the wildcard taxa in the complete analysis) from our second analysis, does not allow us to inspect the relationship of this lineage.

\section{Paleobiogeographic analysis}

A biogeographic analysis of the probainognathian clade as represented in the majority rule consensus tree of the pruned (70-taxa) phylogenetic analysis was performed in RASP 4.2 [65]. The cladogram branch-length was temporally calibrated with RStudio [66] using PaleoTree package [67] with EQUAL methodology. The First Appearance Datum (FAD) and Last Appearance Datum (LAD) as well as the geographical distribution of the taxa were obtained from the relevant published sources (see [28] and [4] for a review). We considered nine ancestral areas according to the regions that fossils were found (Supplementary Table S1). Most areas are so distant from each other that it is not necessary to determine discontinuity between them. Additionally, almost all of them have only endemic taxa. We performed a Bayesian Binary Markov Chain Monte Carlo (BBM; [68]) analysis with the calibrated cladogram, considering 100,000 cycles, 100 chains, and the maximum number of areas (nine) per node. We conducted an optimization analysis to test the possible ancestral area of relevant nodes using the Weighted Ancestral Area Analysis (WAAA; [44]). The number of weighted gain steps (GSW), weighted loss steps (LSW) and the probability index (PI = GSW/LSW) were calculated manually. The PI of each area indicates the probability of that area as a part of the ancestral area.

\section{Declarations}

Acknowledgements 
We thank the Secretaría de Cultura de La Rioja and the Administración de Parques Nacionales for granting permits to perform fieldwork in the Parque Nacional Talampaya. We thank the rangers at this national park for the continuous aid along many years. We are thankful to the Museo de Ciencias Naturales, Universidad Nacional de La Rioja, the Autoridad de Aplicación Nacional ley 25.743, the Departamento de Comercio Internacional de la CNEA, and Sergio Soria for making it possible to temporally transport the fossil specimen to be CT-scanned in Germany. We acknowledge the team from the RA-6 neutron reactor (CNEA) and from Y-TEC for performing tomography analyses of the specimen. This work is based upon experiments performed at the ANTARES instrument operated by FRM II at the Heinz Maier-Leibnitz Zentrum (MLZ), Garching, Germany. This study benefited from the input of Cecilia Cataldo, Agustin Martinelli, Spencer Lucas, Ben Kligman, Julian Benoit, and Fernando Novas. This research was partially funded by the Agencia Nacional de Promoción Científica y Tecnológica (PICT 2015-0504 and 2017-1487), the Consejo Nacional de Investigaciones Científicas y Técnicas (CONICET-PIP 11220150100760CO), Sepkosky Grant (to LCG) and The Explorers Club Grant (to AO). This is LCG's R-408 contribution to the IDEAN.

\section{Author contributions}

LCG and FA led the writing of the main manuscript text, the supplemental text, and performed the phylogenetic analysis. LCG, FA, FDS, and VK designed and prepared the figures. FDS performed the paleobiogeographic analysis and interpreted the results. LCG, AT, and MS conceived the experimental design and conducted the neutron tomography analysis. MS made the tomographic reconstruction and LCG segmented the reconstructed images. AO performed the X-ray tomography of the specimen. LCG, AO, $J M L, C A$, and VK participated from the finding of the specimen. ES provided technical aid for the processing the reconstructed tomographic images. All authors contributed to the editing of the manuscript and its Supplementary Information.

\section{Additional information}

Competing interests. The authors declare no competing interests.

Supplementary information is available for this paper online.

Correspondence and requests for materials should be addressed to LCG.

\section{References}

1. Rowe, T. Definition, diagnosis and origin of Mammalia. J. Vertebr. Paleontol. 8, 241-264 (1988).

2. Hopson, J. A. \& J. W. Kitching. A probainognathian cynodont from South Africa and the phylogeny of non-mammalian cynodonts. B. Mus. Comp. Zool. 156, 5-35 (2001). 
3. Abdala, F. \& Gaetano, L. C. Late Triassic cynodont life, time of innovations in the mammal lineage in: The Late Triassic World - Earth in a Time of Transition (ed. Tanner, L. H.) 407-445 (Springer's Geobiology book series, 2018).

4. Abdala, F. et al. The Triassic cynodonts from Argentina: a Gondwanan perspective. J. S. Am. Earth Sci. 104, 102884; 10.1016/j.jsames.2020.102884 (2020).

5. Bonaparte, J. F. Los tetrápodos del sector superior de la Formación Los Colorados, La Rioja, Argentina. Opera Lilloana 22, 1-183 (1971).

6. Arcucci, A. B., Marsicano, C. A. \& Caselli, A. T. Tetrapod association and palaeoenviroment of the Los Colorados Formation (Argentina): a significant sample from Western Gondwana at the end of the Triassic. Geobios 37, 557-568 (2004).

7. Domnanovich, N. Revisión de los dicinodontes kannemeyéridos (Amniota, Therapsida) de Argentina, relaciones filogenéticas e implicancias paleobiogeográficas. Universidad de Buenos Aires, Buenos Aires, Argentina. PhD Thesis 387pp. (2010).

8. Martínez, R. et al. A new Late Triassic vertebrate assemblage from northwestern Argentina. Ameghiniana 52, 379-390 (2015).

9. Colombi, C. et al. Bonebed en las facies basales de la Formación Los Colorados (Noriano), Cuenca de Ischigualasto-Villa Unión, San Juan, Argentina. Resúmenes Reunión de Comunicaciones de la Asociación Paleontológica Argentina, Puerto Madryn (2018).

10. Colombi C. et al. A high-precision $\mathrm{U}-\mathrm{Pb}$ zircon age constraints the timing of the faunistic and palynofloristic events of the Carnian Ischigualasto Formation, San Juan, Argentina. J. S. Am. Earth Sci. 111, 103433; 10.1016/j.jsames.2021.103433 (2021).

11. Rougier, G., de la Fuente, M. S. \& Arucci, A. B. Late Triassic turtles from South America. Science 268, 855-858 (1995).

12. Sterli, J., de la Fuente, M. S. \& Rougier, G. W. Anatomy and relationships of Palaeochersis talampayensis, a Late Triassic turtle from Argentina. Palaeontographica Abteilung A 281, 1-61 (2007).

13. Bonaparte, J. F. Los tetrápodos triásicos de Argentina. Gondwana Stratigraphy, I. U.G.S. Coloquio Mar del Plata 1967, 307-325 (1969).

14. Bonaparte, J. F. Annotated list of the south American Triassic tetrapods. Proceedings and Papers: Second Gondwana Symposium, South Africa 1970, 665-682 (1970).

15. Martínez, R. N., Alcober, O. A. \& Pol, D. A new protosuchid crocodyliform (Pseudosuchia, Crocodylomorpha) from the Norian Los Colorados Formation, northwestern Argentina. J. Vertebr. Paleont. 38, e1491047; 10.1080/02724634.2018.1491047 (2019).

16. Leardi, J. M., Yañez, I. \& Pol, D. South American crocodylomorphs (Archosauria; Crocodylomorpha): a review of the early fossil record in the continent and its relevance on understanding the origins of the clade. J. S. Am. Earth Sci. 104, 102780; 10.1016/j.jsames.2020.102780 (2020).

17. Bonaparte, J. F. Coloradia brevis n. g. et n. sp. (Saurischia Prosauropoda), dinosaurio Plateosauridae de la Formación Los Colorados, Triásico Superior de la Rioja, Argentina. Ameghiniana 15, 327-332 
(1978).

18. Bonaparte, J. F. Evolución de las vértebras presacras en Sauropodomorpha. Ameghiniana 36, 115187 (1999).

19. Arcucci, A. B. \& Coria, R. A. A new Triassic carnivorous dinosaur from Argentina. Ameghiniana 40, 217-228 (2003).

20. Martínez, R. N., Alcober, O. A. Heredia, G. \& Colombi, C. E. Nuevos prosaurópodos de la Formación Los Colorados (Triásico Superior-Noriano), La Rioja, Argentina. Ameghiniana 41, 55R (2004).

21. Ezcurra, M. D. \& Apaldetti, C. A robust sauropodomorph specimen from the Upper Triassic of Argentina and insights on the diversity of the Los Colorados Formation. Proc. Geologist Assoc. 123: 155-164, 10.1016/j.pgeola.2011.05.002 (2011).

22. Ezcurra, M. D. A new early coelophysoid neotheropod from the Late Triassic of northwestern Argentina. Ameghiniana 54, 506-538 (2017).

23. Irmis, R. B. Evaluating hypotheses for the early diversification of dinosaurs. Earth Env. Sci. T. R. So. Edinburgh 101, 397-426 (2011).

24. Bonaparte, J. F. El primer ictidosaurio (Reptilia, Therapsida) de América del Sur, Chaliminia musteloides, del Triásico Superior de La Rioja. I/ Congreso Argentino de Paleontología y Bioestratigrafía, Buenos Aires 1, 123-133 (1980).

25. Martinelli, A. G. \& Rougier, G. W. On Chaliminia musteloides (Eucynodontia: Tritheledontidae) from the Late Triassic of Argentina, and a phylogeny of Ictidosauria. J. Vertebr. Paleontol. 27, 442-460 (2007).

26. Gaetano, L.C., Abdala, F. \& Govender, R. The postcranial skeleton of the Lower Jurassic Tritylodon longaevus from Southern Africa. Ameghiniana 54, 1-35 (2017).

27. Luo, Z.-X. Sister-group relationships of mammals and transformations of diagnostic mammalian characters in: In the Shadow of the Dinosaurs (eds. Fraser, N. C., Sues, H.-D.) 98-128 (Cambridge University Press, 1994).

28. Ruta, M., Botha-Brink, J., Mitchell, S. A. \& Benton, M. J. The radiation of cynodonts and the ground plan of mammalian morphological diversity. Proc. R. Soc. B 280, 20131865;

10.1098/rspb.2013.1865 (2013).

29. Martinelli, A. G. et al. The African cynodont Aleodon (Cynodontia, Probainognathia) in the Triassic of southern Brazil and its biostratigraphic significance. PLOS ONE 12, e0177948;

10.1371/journal.pone.0177948 (2017a)

30. Gaetano, L. C. et al. New cynodont specimens from Los Colorados Formation. Publicación Electrónica de la Asociación Paleontológica Argentina 19, R50 (2019).

31. Kent, D. V., Santi Malnis, P., Colombi, C. E., Alcober, O. A. \& Martínez, R. Age constraints on the dispersal of dinosaurs in the Late Triassic from magnetochronology of Los Colorados Formation (Argentina). PNAS 111, 7958-7963 (2014). 
32. Desojo, J. B. et al. The Late Triassic Ischigualasto Formation at Cerro Las Lajas (La Rioja, Argentina): fossil tetrapods, high-resolution chronostratigraphy, and faunal correlations. Sci. Rep. 10, 12782; 10.1038/s41598-020-67854-1 (2020).

33. Schwarz, D., Meyer, C. A., Lehmann, E. H., Vontobel, P. \& Bongartz, G. Testing Neutron tomography in comparison with X-ray computed tomography as a technique for the investigation of the internal structure of sauropod vertebrae and ribs. Palaeontol. Electron. 8, 1-11 (2005).

34. Laaß, M. \& Schillinger, B. Reconstructing the auditory apparatus of therapsids by means of neutron tomography. Physcs. Proc. 69, 628-635 (2015).

35. Broom, R. On the use of the term Anomodontia. Records of the Albany Museum 1, 266-269 (1905).

36. Owen, R. Palaeontology, or a Systematic Summary of Extinct Animals and their Geological Relations. Second Edition. 1-463. (Adam and Charles Black, 1861).

37. Kemp, T.S. Mammal-like Reptiles and the Origin of Mammals 1-363 (Academic Press, 1982).

38. Hopson, J. A. 1990. Cladistic analysis of therapsid relationships. Journal of Vertebrate Paleontology 10 (Supplement 3): 28A.

39. Kermack, K. A., Mussett, F. \& Rigney, H. W. The skull of Morganucodon. Zool. J. Linn. Soc. 53, 87-175 (1981).

40. Benoit, J. et al. The evolution of the maxillary canal in Probainognathia (Cynodontia, Synapsida): reassessment of the homology of the infraorbital foramen in mammalian ancestors. J. Mammal. Evol. 27, 329-348 (2020).

41. Benoit, J., Manger, P. R. \& Rubidge, B. S. Palaeoneurological clues to the evolution of defining mammalian soft tissue traits. Sci Rep 6, 25604; https://doi.org/10.1038/srep25604 (2016).

42. Liu, J. \& Olsen, P. The phylogenetic relationships of Eucynodontia (Amniota: Synapsida). J. Mammal Evol. 17, 151-176 (2010).

43. Abdala, F. Redescription of Platycraniellus elegans (Therapsida, Cynodontia) from the Lower Triassic of South Africa, and the cladistic relationships of eutheriodonts. Palaeontology 50, 591-618 (2007).

44. Hausdorf, B. Weighted area analysis and a solution of the redundant distribution problem. Syst. Biol. 47, 445-456 (1998).

45. Datta, P. M. \& Das, D. P. Discovery of the oldest fossil mammal from India. India Min. 50, 217-222 (1996).

46. Datta, P. M. Earliest mammal with transversely expanded upper molar from the Late Triassic (Carnian) Tiki Formation, South Rewa Gondwana Basin, India. J. Vert. Paleontol. 25, 200-207 (2005).

47. Bhat, M. S. Ray, S. \& Datta, P. M. New cynodonts (Therapsida, Eucynodontia) from the Late Triassic of India and their significances. J. Paleontol. 95, 376-393 (2021).

48. Kielan-Jaworowska, Z., Cifelli, R. \& Luo, Z.-X. Mammals from the age of dinosaurs: origin, evolution and structure 1-630 (Columbia University Press, 2004). 
49. Debuysschere, M., Gheerbrant, E. \& Allain, R. Earliest known European mammals: a review of the Morganucodonta from Saint-Nicolas-de-Port (Upper Triassic, France). J. Sys. Palaeontol. 13, 825855; 10.1080/14772019.2014.960486 (2015).

50. Luo, Z.-X. \& Martin, T. Analysis of molar structure and phylogeny of docodont genera. Bull. Carnegie Mus. Nat. Hist. 39, 27-47 (2007).

51. Mancuso, A. C. et al. The Chañares formation: a window to a Middle Triassic tetrapod community. Lethaia 47, 244-265 (2014).

52. Martínez, R. et al. New basal dinosaur from the dawn of the dinosaur era in Southwestern Pangea. Science 31, 206-210 (2011).

53. Martinelli, A. G., Eltink, E., Da-Rosa, Á. A. S. \& Langer, M. C. A new cynodont (Therapsida) from the Hyperodapedon Assemblage Zone (upper Carnian-Norian) of southern Brazil improves the Late Triassic probainognathian diversity. Pap. Palaeontol. 3, 401-423 (2017b).

54. Oliveira, T. V., Soares, M. B. \& Schultz, C. L. Trucidocynodon riograndensis gen. nov. et sp. nov. (Eucynodontia), a new cynodont from the Brazilian Upper Triassic (Santa Maria Formation). Zootaxa 2382, 1-71 (2010).

55. Ruffell, A., Simms, M. J. \& Wignall, P. B. The Carnian Humid Episode of the late Triassic: a review. Geol. Mag. 153, 271-284; 10.1017/S0016756815000424 (2016).

56. Calzada, E., Gruenauer, F., Muehlbauer, M., Schillinger, B. \& Schulz, M. New design for the ANTARES-II facility for neutron imaging at FRM II. Nucl. Instrum. Methods Phys. Res. Sect. A. Accel. Spectrom. Detect. Assoc. Equip. (2009)

57. Schulz, M. \& Schillinger, B. Cold neutron radiography and tomography facility. J. Large-Scale Res. Facil. 1,17; 10.17815/jlsrf-1-42 (2015).

58. Rasband, W. S., ImageJ, U. S. National Institutes of Health, Bethesda, Maryland, USA. https://imagej.nih.gov/ij/ (1997-2018).

59. Kaestner, A. P. \& Schulz, M. Processing neutron imaging data - quovadis? Physcs. Proc. 69, 336-342; 10.1016/j.phpro.2015.07.047 (2015).

60. Kaestner, A. \& Carminati, C. Neutronimaging/KipTool: First official release of KipTool. http://dx.doi.org/10.5281/zenodo.2578798 (2019).

61. Carminati, C. Strobl, M. \& Kaestner, A. KipTool, a general purpose processing tool for neutron imaging data. SoftwareX 10, 100279; 10.1016/j.softx.2019.100279 (2019).

62. Burger, M., Gilboa, G., Osher, S. \& Xu, J. Nonlinear inverse scale space methods. Commun. Math. Sci. 4,179-212 (2006).

63. Goloboff, P., Farris, J.S., \& Nixon, K. TNT, a free program for phylogenetic analysis. Cladistics 24, 774-786 (2008).

64. Goloboff, P. \& Catalano, S. TNT version 1.5, including a full implementation of phylogenetic morphometrics. Cladistics 32, 221-238 (2016). 
65. Yu, Y., Blair,C. \& He, X. J. RASP 4: Ancestral State Reconstruction Tool for Multiple Genes and Characters. Mol. Biol. Evol. 37, 604-606 (2020).

66. R Core Team. R: A language and environment for statistical computing. R Foundation for Statistical Computing, Vienna, Austria. https://www.R-project.org/ (2021).

67. Bapst, D. W. Paleotree: an R package for paleontological and phylogenetic analyses of evolution. Methods Ecol. Evol. 3, 803-807; 10.1111/j.2041-210X.2012.00223.x (2012).

68. Ronquist, F. \& Huelsenbeck, J. P. MrBayes3: Bayesian phylogenetic inference undermixed models. Bioinformatics 19, 1572-1574 (2003).

69. Scotese, C. R. Atlas of Earth History Vol. 1, Paleogeography, 52 pp. (PALEOMAP Project, 2001).

\section{Figures}

\section{Figure 1}

Geographic location of the 'La Esquina' locality where Tessellatia bonapartei holotype (PULR-V121) was found. (a) Southern South America; (b) satellite image of north-western Argentina depicting the study area (green, dotted-line rectangle) within the Talampaya National Park, La Rioja Province; (c) satellite image showing the main outcrops of the Los Colorados Formation where the rich faunal assemblage of the 'La Esquina' locality was found (yellow, dotted-line rectangle); (d) photograph of the outcrops at the 'La Esquina' locality portraying the levels from where Tessellatia bonapartei holotype (PULR-V121) was recovered. Satellite images from Google Earth, accessed December 2021.

\section{Figure 2}

Tessellatia bonapartei holotype specimen (PULR-V121). (a) Cranium as preserved in right lateral view; (b) 3D model of the cranium in right lateral view; (c) interpretation line drawing of the skull and right lower jaw (restored to its natural position) in right lateral view; (d) digital render of the skull showing the roots of the anterior upper postcanines, not visible externally; (e) 3D model of the osseous secondary palate and upper teeth in ventral view; (f) interpretation line drawing of the osseous secondary palate and upper teeth in ventral view; (g) right lower jaw in dorsal view; (h) right lower jaw in medial view; (i) 3D model of the pc4 in labial, occlusal and lingual views (from left to right); (j) 3D model of PC9 and PC10 pc4 in labial, occlusal and lingual views (from left to right). aac anterior accessory cusp, an angular process, $C / C$ upper/lower canines, cin cingulum, co coronoid, $d$ dentary, fr frontal, // $i$ upper/lower incisors, iof infraorbital foramen, / lacrimal, $m c$ main cusp, $m f$ masseteric fossa, $m x$ maxilla, $n$ nasal, pac posterior accessory cusp, $p a /$ palatine, $P C / p c$ upper/lower postcanines, $p m x$ premaxilla, $p t$ pterygoid. Scale bars ah: $5 \mathrm{~mm} ; \mathrm{i}-\mathrm{j}: 2.5 \mathrm{~mm}$. 


\section{Figure 3}

Tessellatia bonapartei holotype specimen (PULR-V121). Neutron tomography image of a transversal cross-section of the cranium showing the ossified maxillary canal.

\section{Figure 4}

Equal length calibrated, strict consensus tree of the pruned data matrix.

\section{Figure 5}

Paleogeographic reconstructions depicting dispersion events in different time-slices according to the RASP analysis and the calibrated majority rule consensus tree of the pruned data matrix. Areas are represented by circles: Violet Brazil, Blue Argentina, Musk Green Namibia, Orange South Africa, Dark Brown Madagascar, Dark blue Tanzania, Light blue North America, Light brown China, and Dark Green Europe. Arrows in each time-slice represent dispersions at different moments of the corresponding age: yellow early, orange middle, and red late. Yellow-circled area in the paleogeographic reconstruction of the Olenekian time-slice represents that Probainognathia originated in Brazil by the early Olenekian. Dotted lines in the paleogeographic reconstruction of the Olenekian time-slice indicate that after the dispersion form Brazil to Namibia, a new joint area (Brazil-Namibia) was established and from there dispersions occurred to Argentina and Madagascar. Pie charts showing the probability of different ancestral areas for selected major clades. Asterisk depicts the probability of all those areas that have less than $5 \%$ probability of being the ancestral area of a node taken together. Paleogeographic reconstructions from [69].

\section{Supplementary Files}

This is a list of supplementary files associated with this preprint. Click to download.

- GaetanoetalSupplementaryInformation.docx

- GaetanoetalSupplemetaryAppendixS1Anotatedphylogeneticdatamatrix.nex 